\title{
Socioeconomic factors of child basic immunization: Case of West Java Province
}

\author{
Patrisia Helena Saraswati ${ }^{1}$, Ascobat Gani ${ }^{2}$ \\ ${ }^{1}$ Correspondence Author: patrisiahsp@gmail.com
}

${ }^{1}$ Department of Administration and Health Policy, Faculty of Public Health, University of Indonesia, Indonesia 2Department of Administration and Health Policy, Faculty of Public Health, University of Indonesia, Indonesia

\begin{tabular}{l}
\hline I N D E X I N G \\
\hline Keywords: \\
Child Immunization; \\
Socio-Economic \\
Factor; \\
West Java.
\end{tabular}

Kata Kunci: Imunisasi Anak; Faktor Sosial Ekonomi; Jawa Barat. \begin{abstract}
A B S T R AC T
Indonesia has committed to eradicating infectious diseases by launching an Expanded Program on Immunization (EPI) in 1977 with a focus on 6 diseases: tuberculosis, diphtheria, tetanus, pertussis, measles, and polio. According to the Basic Health Survey (RISKESDAS) 2018, the rate of basic immunization coverage for children in Indonesia was still below $60 \%$ and coverage between provinces varies. West Java was among the province with low child basic immunization coverage. The current study is designed to examine the socio-economic factors that influence child basic immunization using logistic regression. Socioeconomic data were extracted from the National Socioeconomic Survey (Susenas) 2017 and Village Potential (Podes) Survey 2018. The study finds that income, maternal education, location of residence, insurance ownership, availability of health facilities and health workers increase the likelihood of children getting immunized.
\end{abstract}

\begin{abstract}
Indonesia telah memiliki komitmen untuk eradikasi penyakit menular dengan menjalankan Expanded Programme on Immunization (EPI) pada tahun 1977 dengan fokus pada 6 penyakit: TBC, difteri, tetanus, pertussis, campak dan polio. Menurut data Riset Kesehatan Dasar (RISKESDAS) 2018 angka cakupan imunisasi dasar anak di Indonesia masih dibawah 60\% dan cakupan antar provinsi bervariasi. Jawa Barat adalah salah satu provinsi dengan cakupan imunisasi dasar anak yang rendah. Penelitian saat ini dirancang untuk memeriksa faktor-faktor sosial ekonomi yang mempengaruhi imunisasi dasar anak menggunakan regresi logistik. Data sosial ekonomi diambil dari Survei Sosial Ekonomi Nasional (Susenas) 2017 dan Survei Potensi Desa (Podes) 2018. Studi menemukan bahwa pendapatan, pendidikan ibu, lokasi tempat tinggal, kepemilikan asuransi, ketersediaan fasilitas kesehatan dan tenaga kesehatan meningkatkan kemungkinan anak-anak diimunisasi.
\end{abstract}

(C) 2020 JMMR. All rights reserved

Article History: Received 2019-Nov-07; Revised 2020-01-10; Accepted 2020-02-24

\section{INTRODUCTION}

Immunization has proven to be the most cost-effective and safest health intervention program that reduces mortality and morbidity and increases the quality of life (Andre et al., 2008; M. Doherty et al., 2016; Favin et al., 2012; Greenwood, 2014). The benefits of immunization arise, either directly through immunity for those who obtain it or indirectly by developing herd immunity or immunity to other individuals in a broad environment (Andre et al., 2008). In 1974, the World Health Organization (WHO) launched the Expanded Program on Immunization (EPI), a global immunization program to ensure every child gets the benefits of immunization. The program has successfully increased the global vaccine coverage to above $70 \%$ in 2005 but there are variations between countries. The average immunization coverage in the European Union (EU) for diphtheria, pertussis, and tetanus (DPT) reach $99 \%$ but coverage in Malta is only 76\%, Austria 83\% and Latvia 89\% (E. Doherty et al., 2014). Variation in vaccine coverage is also found in low- and middle-income countries (Hosseinpoor et al., 2016).

Indonesia has committed to eradicating infectious diseases by launching EPI in 1977 with a focus on 6 diseases: tuberculosis (BCG), diphtheria, tetanus, pertussis (DTP vaccine), measles, and poliomyelitis (Barnum et al., 1980). Immunization program in Indonesia has 
resulted in smallpox eradication in 1974, free polio status in 2014 and elimination of maternal and neonatal tetanus in 2016. Although national immunization coverage continues to increase and immunization is provided free at community health centers (puskesmas), there are still areas in Indonesia where immunization coverage is low (Herliana \& Douiri, 2017; Maharani \& Tampubolon, 2015).

Based on the Basic Health Research survey (RISKESDAS), the national basic immunization coverage for children in 2013 was only $59.2 \%$ and decreased to $57.9 \%$ in 2018. Coverage at the provincial level varied from $19.5 \%$ (Aceh) to $92.1 \%$ (Bali). The rates were alarming as they were way below the target rate to achieve herd immunity.

Previous studies have shown the association of socio-economic factors with child immunization. Socio-economic factors such as household income, maternal education, residential status, number of siblings, insurance ownership, tribe, sex, parental occupational status, were found to be significantly associated with child immunization (Adenike et al., 2017; Bhuiya et al., 1995; E. Doherty et al., 2014; Herliana \& Douiri, 2017; Lauridsen \& Pradhan, 2011). Understanding the socio-economic factors of immunization is crucial for developing further interventions to increase coverage (Adenike et al., 2017; Bhuiya et al., 1995; E. Doherty et al., 2014; Herliana \& Douiri, 2017; Lauridsen \& Pradhan, 2011).

A number of studies evaluated the socio-economic factors of child immunization at the national level but assessment on what happens at the provincial level is limited (Herliana \& Douiri, 2017; Maharani \& Tampubolon, 2015). Assessment at the provincial level is needed as the immunization program is designed and conducted by the local governments both at the provincial and district levels. Based on RISKESDAS 2018, West Java is among the provinces with the lowest child immunization coverage in Indonesia (58.3\%). West Java was also hit by measles and diphtheria outbreak in 2015 and 2017(Harapan et al., 2019). This study analyses the socio-economic factors of basic immunization in West Java.

\section{RESEARCH METHOD}

The research combined household survey data from the 2017 National SocioEconomic Survey (Susenas) and 2018 Village Potential (Podes). Information on immunization status and the following household socio-economic characteristics were taken from Susenas: household income, mother's level of education, residential status (urban/rural), child insurance coverage, household head's access to the internet. Data on health facilities and health personnel were obtained from Podes. For the purpose of the study, only health facilities that provide immunization services were used: hospitals, community health centers (puskesmas), and village health posts (posyandu). Meanwhile, for data on health workers, we use medical doctors and other health workers. The information generated from Podes was linked with household characteristics used in Susenas using the municipality ID that both data use.

Information on immunization in SUSENAS was obtained based on the respondent's responses. Susenas asked parents whether they had their children receive the following basic immunizations: BCG (tuberculosis), polio, DPT (diphtheria, tetanus, and pertussis), measles and hepatitis B. Out of 4,843 children, only $31 \%$ were able to show immunization cards with $52 \%$ failing to show immunization cards and the remaining $17 \%$ with no immunization cards. The low percentage of immunization cards shown to the enumerators may cause 
recalled bias. We only counted at least one dose of each type of child basic immunization (based on EPI standard) to avoid bias. If children received at least one dose of each vaccine (total 5 doses), we classified the children as immunized $(=1)$ while children who did not receive each vaccine or not receiving any immunization were classified as not immunized $(=0)$.

To answer whether the independent variable has an association with the probability of children age 12-59 months being immunized, we used logistic regression and built the following model:

Yi $=\beta_{0}+\beta_{1} X_{1}+\beta_{2} X_{2}+\beta_{3} X_{3}+\ldots \ldots \beta_{n} X n+e$

Where $\mathrm{Yi}$ as the dependent variable/variable of interest is binary data. In logistic regression, the dependent variable y has 2 values with a probability of $\mathrm{p}$. This model focuses on the determinant of the probability of $\mathrm{p}$ on an outcome and not on its alternative probability, 1-p.

$Y i=\left\{\begin{array}{l}1, \text { with probability } p \\ 0, \text { with probability } 1-p\end{array}\right.$

The model was determined as follows:

$Y i=\beta_{0}+\beta_{1} x+\beta_{2}$ mom $_{\text {seh }}+\beta_{3}$ commune $+\beta_{4}$ hh $_{\text {ins }}+$
$\beta_{5}$ hh $_{\text {inet }}+\beta_{6} r s_{1000}+\beta_{7}$ puskesmas $_{1000}+$
$\beta_{8}$ posyandu $_{1000}+\beta_{9}$ dokter $_{1000}+\beta_{10}$ nakeslain $_{1000}+e$

With,

Yi : Children aged 12-59 months who received at least 1 (one) dose of each type of vaccination of basic child immunization (BCG, DPT, polio, measles, hepatitis B). Binary variable with $1=$ immunized; $0=$ unimmunized

$\mathrm{x} \quad$ : expenditure per capita per person (in the form of a log)

Commune : residence status $(1=$ urban and $0=$ rural $)$

mom_sch : mother's education (years of schooling)

h_ins $\quad$ : child insurance coverage $(1=$ own insurance and $0=$ no insurance $)$

h_inet $\quad$ : Household head's access to internet $(1=$ access and $0=$ no access $)$

rs_1000 : ratio of hospitals per 1000 population

Puskesmas_1000: ratio of community health centers per 1000 population

Posyandu_1000: ratio of village health posts per 1000 population

doctor_1000 : ratio of doctors per 1000 population

nakeslain_1000: ratio of other health workers per 1000 population

\section{Descriptive Analysis}

\section{RESULTS AND DISCUSSION}

A descriptive statistics table shows that from a total of 4,843 children, $74.87 \%$ of children received at least 1 dose of each type of basic immunization. The remaining $25.13 \%$ of children do not have complete immunization or do not receive any immunization. This means that West Java is missing the WHO immunization target and failing to provide basic primary care services. Figure 1. Highlights the variation between municipalities in West Java. Only 7 out of 27 municipalities have coverage above $80 \%$ and there are 2 municipalities which coverage is lower than $40 \%$. 


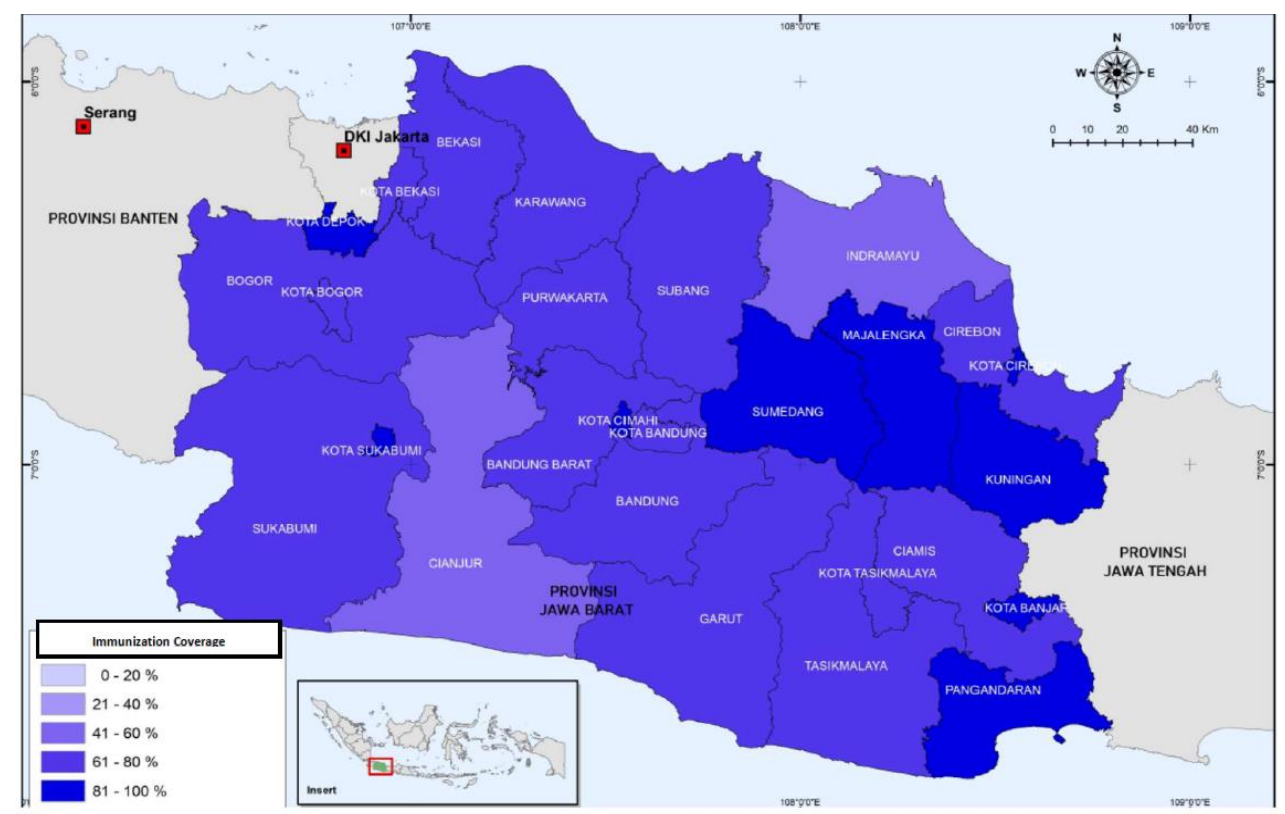

Figure 1. Child Basic Immunization Coverage in West Java 2017 Source: Susenas 2017

This wide gap between districts urges an in-depth analysis of the municipalities and individual levels.

Table 1. Descriptive statistics

\begin{tabular}{|c|c|c|c|c|c|}
\hline Variable & Description & Obs & Mean & Std. Dev. & $\%$ \\
\hline \multirow[t]{3}{*}{ ch_vasn } & Basic child immunization & 4,843 & 0.749 & 0.4338 & \\
\hline & $1=$ immunized & & & & 74,87 \\
\hline & $0=$ unimmunized & & & & 25,13 \\
\hline $\mathrm{x}$ & Expenditure per capita $(\log )$ & 4,843 & 13.476 & 0.6520057 & \\
\hline \multirow[t]{3}{*}{ commune } & Residential status & 4,843 & 0.663 & 0.473 & \\
\hline & $1=$ urban & & & & 66.26 \\
\hline & $0=$ rural & & & & 33.74 \\
\hline mom_sch & Mother's years of schooling & 4,843 & 9.279 & 3.446892 & \\
\hline \multirow[t]{3}{*}{ h_ins } & Child insurance ownership & 4,843 & 0.414 & 0.492527 & \\
\hline & $1=$ own an insurance & & & & 41,36 \\
\hline & $0=$ no insurance & & & & 58,64 \\
\hline \multirow[t]{3}{*}{ h_inet } & Parent's access to internet & 4,843 & 0.387 & 0.4871981 & \\
\hline & $1=$ have access to internet & & & & 38,74 \\
\hline & $0=$ no access & & & & 61,26 \\
\hline rs_1000 & Hospital/1000 population & 4,844 & 0.013 & 0.0099705 & \\
\hline puskesmas_1000 & Puskesmas/1000 population & 4,844 & 0.074 & 0.0329677 & \\
\hline posyandu_1000 & Posyandu/1000 population & 4,844 & 1.24 & 0.347672 & \\
\hline dokter_1000 & Dokter/1000 population & 4,844 & 0.152 & 0.0855732 & \\
\hline nakeslain_1000 & $\begin{array}{l}\text { Other health worker/1000 } \\
\text { population }\end{array}$ & 4,844 & 0.45 & 0.2101071 & \\
\hline
\end{tabular}

Source: Susenas 2017 and Podes 2018

According to Podes 2018, there were 590 hospitals in West Java, which included general hospitals and specialized maternity hospitals. The ratio of hospitals per 1000 
population was around 0.013 . Figure 2 . Shows the variation of the ratio of hospital per 1000 population between municipalities.

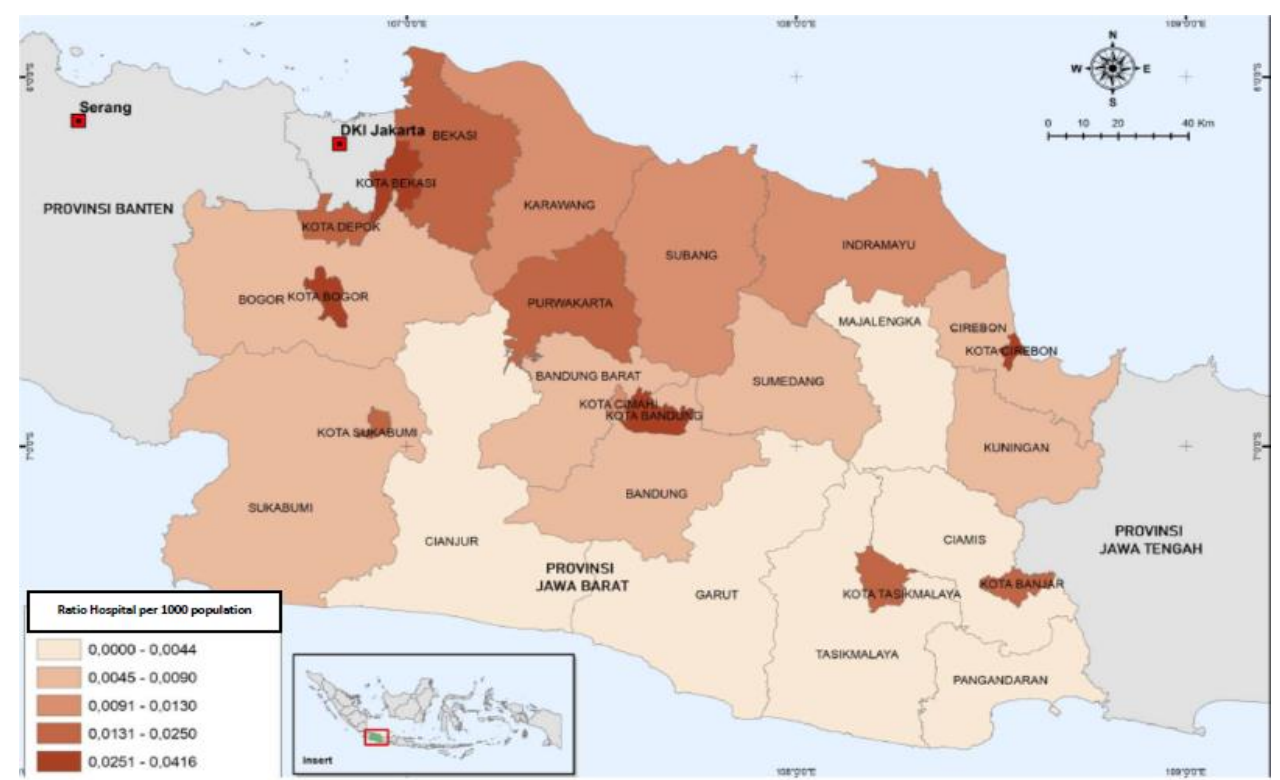

Figure 2. The ratio of hospital per 1,000 populations by municipalities Source: Podes 2018

The total number of community health centers in 27 municipalities was 3,142, consisting of community health centers with inpatient care and community health centers with only outpatient care. The ratio of community health centers per 1000 population is 0.074 or 74 community health centers serving 1 million populations. There were 56,700 village health posts and the ratio per 1,000 populations was 1.238 . Village health posts have the highest ratio among the three types of health facility but it does not accessible every day. Village health posts operate once a month (or more).

West Java had less than 1 doctor per 1000 population. There were only 0.152 doctors per 1000 population or 15 doctors serving 100,000 people while the ratio of other health workers per 1000 population was 0.45 or 45 health workers serving 100,000 people. The average mother's level of education in West Java is considered low. The average mother's years of schooling is 9.28 years or not completing junior secondary school. The range of years of schooling is from Year 0 or no education to Year 19 at undergraduate level. Almost half of the children aged 12-59 months in West Java have insurance coverage (41.36\%). Then 38.74 $\%$ household head has internet access. Having internet access allows parents to get information about immunization.

\section{Bivariate Analysis}

The bivariate test of the independent variables shows a significant relationship of all variables tested with the dependent variable ( $p$-value $<0.001)$. Community health centers variable $p$-value slightly above the significance of the cut-off value used $(p<0.025)$. However, theoretically, community health centers are important to explain immunization. Therefore, community health centers variable along with other numerical variables will be included in the multivariate analysis. 
Chi-square test results for 3 (three) independent categorical variables: residence status, child insurance ownership and household head's internet access, show a significant relationship between complete basic immunization with the child's residence $(2, \mathrm{~N}=4,843)=$ 25.02, $\mathrm{p}=0.001$, child insurance ownership $(2, \mathrm{~N}=4,843)=13.21, \mathrm{p}=0.001$ and household head internet access $(2, \mathrm{~N}=4,843)=29.91, \mathrm{p}=0.001$, so that all three variables can be included in multivariate analysis.

\section{Multivariate Analysis}

Table 2 shows the result of logistic regression analyses. Income, mother's level of education, geographical location, child insurance coverage, the ratio of the hospital, community health centers, village health posts, doctor and health workers per 1,000 population are all statistically significant at 5\%. Among the independent variables, it seems that the ratio of community health centers to 1,000 population has the most dominant effect to child basic immunization (OR: 62.80; 95\% CI: 1.12, 3504.65; P <0.001), holding all other variables constant. The ratio of doctor and health workers per 1,000 populations is also influential with children having odd 34.7 and 4.9 times of getting basic immunization. Meanwhile, the impact of the ratio of hospital and village health posts per 1,000 populations is very dismal. Children who live in the area with a higher ratio of hospital and village health posts per 1,000 populations are less likely to be immunized than children who live in the area with a lower ratio of hospital and village health posts.

Mothers who have higher education are more likely to immunize their children than mothers with lower or no education. Children who live in an urban area, have better-off families and own health insurance are more likely to be immunized. However, the relationship between the parent's internet access relationship and child basic immunization is not statistically significant.

The overall test of the model shows that there is no misspecification ( $\mathrm{p}$ value $>0.001$ ). A comparison between predicted outcomes and actual outcomes showed that the correctly specified values in this model are $75 \%$ where 3.632 observations are correctly specified. The sensitivity analysis shows that the results are robust.

\section{Discussion}

Since 1977, the government of Indonesia has made sure that every child gets the benefit of immunization by launching the Extended Programmed on Immunization (EPI). After 40 years of the program, immunization coverage has shown a lot of improvement. However, the increasing number of populations, geographical extends and social dynamics has posed many new challenges for immunization.

The coverage in 2017 is still below the WHO target rate to guarantee herd immunity. The national immunization coverage rate may show a rate of around $80-90 \%$, but when we break down to provinces and municipalities, there is a high variation between areas. The alarm of low immunization coverage has been ringing with measles and diphtheria outbreak in 2005 and 2017. If coverage is nowhere to get higher, the government must work hard to find ways to achieve the minimum rate for herd immunity and to reach the whole population, especially the marginalized. 
Table 3. Multivariate Analysis

\begin{tabular}{|l|c|c|c|c|c|}
\hline \multicolumn{1}{|c|}{ Child Immunization } & OR & Std. Error & $\mathrm{p}$ Value & \multicolumn{2}{c|}{$95 \%$ CI } \\
\hline Income & 1.288 & 0.087 & $0.001^{* * *}$ & 1.129 & 1.469 \\
\hline Residence Status (Urban/Rural) & 1.239 & 0.099 & $0.007^{* *}$ & 1.059 & 1.450 \\
\hline $\begin{array}{l}\text { Mother's Level of Education (years of } \\
\text { schooling) }\end{array}$ & 1,044 & 0.013 & $0.001^{* * *}$ & 1.019 & 1.068 \\
\hline Child insurance ownership & 1.199 & 0.091 & $0.016^{*}$ & 1.034 & 1.392 \\
\hline Household head access to internet & 1.050 & 0.088 & 0.560 & 0.891 & 1.238 \\
\hline Hospital/1000 population & $2.88 \mathrm{e}-08$ & $1.79 \mathrm{e}-07$ & $0.005^{* *}$ & $1.44 \mathrm{e}-13$ & 0.006 \\
\hline Puskesmas/1000 population & 62.807 & 128.877 & $0.044^{*}$ & 1.125 & 3504.653 \\
\hline Posyandu/1000 population & 0.573 & 0.110 & $0.004^{* *}$ & 0.393 & 0.836 \\
\hline Doctor/1000 population & 34.714 & 23.763 & $0.001^{* * *}$ & 9.075 & 132.793 \\
\hline $\begin{array}{l}\text { Other health workers/1000 } \\
\text { population }\end{array}$ & 4.942 & 1.192 & $0.001^{* * *}$ & 3.081 & 7.928 \\
\hline Cons & 0.029 & 0.027 & $0.001^{* * *}$ & 0.005 & 0.181 \\
\hline
\end{tabular}

${ }^{*} p<0,05{ }^{* *} p<0,01{ }^{*} 5 \%{ }^{* *} p<0,001$

Multivariate analysis results showed that increasing the number of community health centers, doctors and health workers is important to improve immunization status. Community health centers are located in every sub-district in Indonesia. It plays the role of the first referral and provides basic primary care in the health system. By design, community health centers are responsible to assist village health posts in delivering primary care (Nazri et al., 2016). Based on the Ministry of Health regulation no 75 Year 2014, doctors and health workers from community health centers must support village health posts by training the cadres and also travel to villages to conduct immunization. Immunization services can only be administered by doctors, midwife or vaccinators from community health centers. Coordination between community health centers and village health posts is essential for immunization programs, but it takes community health centers to have enough health workers to serve all villages. Without support from community health centers, village health posts are only able to conduct limited services like baby weighting.

Community health centers also have promotive and preventive functions, so apart from delivering immunization program, community health centers also responsible conducting education and counselling to the population. Based on The Ministry of Health Regulation no. 75 Year 2014 on Community Health Centers there are 5 types of promotive and preventive health workers: environmental health workers, pharmaceutical workers, nutrition workers, public health workers, and health analysts. For community health centers to be able to carry out their functions, they need an appropriate number of health workers. The West Java Province Health Resources data (Dinas Kesehatan Provinsi Jawa Barat, 2017) showed that community health centers are lacking health workers. Only $11 \%$ of the community health centers in West Java had a minimum of five preventive and promotive health workers, the rest did not. This explains why areas with a higher ratio of village health posts have less immunized children than areas with a lower ratio of village health posts. Lacking health resources affects the immunization program in village health posts.

Children in areas with a higher ratio of hospitals are not necessarily better immunized. The fact has shown worse conditions. Hospital is a health establishment that provides curative services, while immunization is prevention care. Hospitals also charge immunization 
services as free immunization only available in community health centers or village health posts. Therefore people tend to go to community health centers (or village health posts) rather than a hospital to get their children immunized (Maharani \& Tampubolon, 2015). The availability of more health facilities and health workers/physicians per population is very important to increase immunization coverage (Mitchell et al., 2008; van Doorslaer et al., 2018). It means that not only the number of health facilities and health workers/physicians that matter; the distribution of health facilities and workers/physicians also affects the ability to reach those who live in the rural, remote areas (Anand \& Bärnighausen, 2007; Paramita et al., 2018).

The importance of health facilities and health workers to increase immunization coverage is also supported by the findings from the analysis of household determinants, were maternal education, household income, residential status and child health insurance influence the likelihood of immunization. Mother's level of education was found to be important for child immunization in the household (Adenike et al., 2017; Desai \& Alva, 1998; McNeil et al., 2019). There are differences between educated and uneducated mothers or mothers with different levels of education, in making decisions. Educated mothers have better information about the benefit of immunization and can access information (Danis et al., 2010; Desai \& Alva, 1998; Herliana \& Douiri, 2017; Maharani \& Tampubolon, 2015). This finding has an important implication on provinces like West Java where the maternal level of education is low. The health sector, including provincial and municipality governments, should be able to identify programs to reach out to the less educated mothers, ways on how to approach them and help them understand immunization (McNeil et al., 2019).

The importance of maternal education to improve immunization coverage is also related to the ability of health workers to provide immunization education. Many studies mention the importance of health workers in providing education about health to the community. Furthermore, the need for health workers who have good communication skills to deliver health messages so that parents who doubt the benefits and safety of immunization can change their minds. Health workers who have a positive perception of immunization will find it easier to invite others to get immunizations, while health workers who doubt the benefits and safety of vaccines will find it difficult to convince others. The data which states that $38 \%$ of household heads in West Java have access to the internet provides information that the internet can be used as a medium for delivering health messages.

Children from households with higher incomes are more likely to be immunized. West Java is among the provinces with the highest number of poorest households in Indonesia (together with East Java and NTT). For the poor and those who live in remote areas (or areas that are geographically difficult to access), the cost of getting immunized is higher (Hodge et al., 2014). Although basic immunization services are funded by the government (free), the cost of going to a health facility and the opportunity cost to bring a child to a health facility is borne by the household (Bhuiya et al., 1995; Herliana \& Douiri, 2017; Hu et al., 2018; Maharani \& Tampubolon, 2015). In areas where the number of health facilities is very limited and geographical conditions are difficult, higher costs, both time and actual transportation cost, to visit health facilities hinder many households get their children immunized. 
As a short-term solution, local governments can provide demand-side subsidy to poor households. Incentives in the form of cash assistance can be given to poor households who have children under 5 years of age who have immunization cards and complete basic immunizations. This form of demand-side subsidy has advantages, where benefits are more targeted and thus reduce the risk of spillover where benefits are received by non-target groups. In the long run, the mechanism requiring basic immunization must be made more assertive, for example by requiring mandatory immunization for children going to primary school. The Italian government, since 2017 and France since 2018 have begun requiring children entering primary school to have complete immunization. This obligation effort is considered to be very effective in increasing immunization coverage and decreasing the immunization gap (Trentini et al., 2019). Efforts to require basic immunization as a condition for school registration must have plans and strategies so that the rejection for moral reasons, beliefs, and philosophies or health reasons, can be controlled. The government needs to be clear about which risks of infectious diseases are greatest and immunization has the legitimacy to be required without exception and which infectious diseases have lower risks and still allow for exclusion for a number of reasons that are considered valid (Arora, K.S, Jacobs, A.J., Morris, 2018).

The availability of insurance coverage increases health consumption. A number of studies have noted that those who have insurance coverage consume far greater health services (Gouda et al., 2016; Herliana \& Douiri, 2017). Indonesia already has a place social health insurance scheme called the BPJS Kesehatan that targets universal coverage in 2019. The data from Susenas 2017 on the lack of insurance coverage for more than $50 \%$ of children in West Java gives the information where BPJS Kesehatan should focus. Both national and local governments can collaborate to increase the subscription of BPJS in West Java.

\section{CONCLUSION}

Child immunization coverage in West Java is still far below the target rate for herd immunity. Outbreaks of measles and diphtheria have become important alarms for the local government to quickly catch up with missed immunizations. To be able to reach out to the high-risk groups, understanding the socio-economic condition of the population is important, especially where there is evidence that socioeconomic factors matter. Community health centers with a sufficient ratio of doctors and health workers to the population should be the main focus to increase immunization coverage. Education programs, counseling for the poor population, especially women with a low level of education, should be designed and launched. Incentives for the poor are also important to increase the demand for immunization by the poor population. Compulsory complete immunization for school entrance is also necessary. And lastly, increased coverage of health insurance such as BPJS can be the driver for better immunization.

There are two limitations of this research: (1) We use multi-sources of cross-sectional data: Susenas 2017 and Podes 2018. The variables tested in this study are limited to the available variables that Susenas and Podes provide, (2) Immunization data is collected based on confession rather than immunization records (only $30 \%$ of the samples have immunization record books), (3) The latest immunization data only available in Susenas 
2017. Starting in 2018, the immunization module in Susenas has been transferred to Riskesdas which raw data are not accessible for the public.

\section{REFERENCE}

Adenike, O. B., Adejumoke, J., Olufunmi, O., \& Ridwan, O. (2017). Maternal characteristics and immunization status of children in north central of Nigeria. Pan African Medical Journal, 26, 1-15. https://doi.org/10.11604/pamj.2017.26.159.11530

Anand, S., \& Bärnighausen, T. (2007). Health workers and vaccination coverage in developing countries: An econometric analysis. Lancet, 369(9569), 1277-1285. https://doi.org/10.1016/S0140-6736(07)60599-6

Andre, F. E., Booy, R., Bock, H. L., Clemens, J., Datta, S. K., John, T. J., Lee, B. W., Lolekha, S., Peltola, H., Ruff, T. A., Santosham, M., \& Schmitt, H. J. (2008). Vaccination greatly reduces disease, disability, death and inequity worldwide. Bulletin of the World Health Organization, 86(2), 140-146. https://doi.org/10.2471/BLT.07.040089

Arora, K.S, Jacobs, A.J., Morris, J. (2018). Refusal of Vaccination: A Test to Balance Societal and Individual Interests. Journal of Clinical Ethicsnical Ethics, 29(3), 206-216. https://doi.org/10.1016/j.physbeh.2017.03.040

Barnum, H. N., Tarantola, D., \& Setiady, I. F. (1980). Cost-effectiveness of an immunization programme in Indonesia. 58(3), 499-503.

Bhuiya, A., Bhuiy, I., \& Chowdhury, M. (1995). Factors affecting acceptance of immunization among children in rural Bangladesh. Health Policy and Planning, 10(3), 304-311. https://doi.org/10.1093/heapol/10.3.304

Danis, K., Georgakopoulou, T., Stavrou, T., Laggas, D., \& Panagiotopoulos, T. (2010). Socioeconomic factors play a more important role in childhood vaccination coverage than parental perceptions: A cross-sectional study in Greece. Vaccine, 28(7), 18611869. https://doi.org/10.1016/j.vaccine.2009.11.078

Desai, S., \& Alva, S. (1998). Maternal education and child health: Is there a strong causal relationship? Demography, 35(1), 71-81. https://doi.org/10.2307/3004028

Dinas Kesehatan Provinsi Jawa Barat. (2017). Data Sumber Daya Manusia Kesehatan.

Doherty, E., Walsh, B., \& O’Neill, C. (2014). Decomposing socioeconomic inequality in child vaccination: Results from Ireland. Vaccine, 32(27), 3438-3444. https://doi.org/10.1016/j.vaccine.2014.03.084

Doherty, M., Buchy, P., Standaert, B., Giaquinto, C., \& Prado-Cohrs, D. (2016). Vaccine impact: Benefits for human health. Vaccine, 34(52), 6707-6714. https://doi.org/10.1016/j.vaccine.2016.10.025

Favin, M., Steinglass, R., Fields, R., Banerjee, K., \& Sawhney, M. (2012). Why children are not vaccinated: A review of the grey literature. International Health, 4(4), 229-238. https://doi.org/10.1016/j.inhe.2012.07.004

Gouda, H. N., Hodge, A., Bermejo, R., Zeck, W., \& Jimenez-Soto, E. (2016). The impact of healthcare insurance on the utilisation of facility-based delivery for childbirth in the philippines. PLoS ONE, 11(12), 1-15. https://doi.org/10.1371/journal.pone.0167268 
Greenwood, B. (2014). The contribution of vaccination to global health: Past, present and future. Philosophical Transactions of the Royal Society B: Biological Sciences, 369(1645). https://doi.org/10.1098/rstb.2013.0433

Gwatkin, D. (2000). Health inequalities and the health of the poor: What do we know? What can we do? Bulletin of World Health Organization, 78(1), 3-18.

Harapan, H., Anwar, S., Dimiati, H., Hayati, Z., \& Mudatsir, M. (2019). Diphtheria outbreak in Indonesia, 2017: An outbreak of an ancient and vaccine-preventable disease in the third millennium. Clinical Epidemiology and Global Health, 7(2), 261-262. https://doi.org/10.1016/j.cegh.2018.03.007

Herliana, P., \& Douiri, A. (2017). Determinants of immunisation coverage of children aged 12-59 months in Indonesia: A cross-sectional study. BMJ Open, 7(12), e015790. https://doi.org/10.1136/bmjopen-2016-015790

Hodge, A., Firth, S., Marthias, T., \& Jimenez-Soto, E. (2014). Location matters: Trends in inequalities in child mortality in Indonesia. Evidence from repeated cross-sectional surveys. PLoS ONE, 9(7). https://doi.org/10.1371/journal.pone.0103597

Hosseinpoor, A. R., Bergen, N., Schlotheuber, A., Gacic-Dobo, M., Hansen, P. M., Senouci, K., Boerma, T., \& Barros, A. J. D. (2016). State of inequality in diphtheria-tetanuspertussis immunisation coverage in low-income and middle-income countries: A multicountry study of household health surveys. The Lancet Global Health, 4(9), e617e626. https://doi.org/10.1016/S2214-109X(16)30141-3

Hu, Y., Liang, H., Wang, Y., \& Chen, Y. (2018). Inequities in Childhood Vaccination Coverage in Zhejiang, Province: Evidence from a Decomposition Analysis on Two-Round Surveys. Mcv, 112. https://doi.org/10.3390/ijerph15092000

Lauridsen, J., \& Pradhan, J. (2011). Socio-economic inequality of immunization coverage in India. Health Economics Review, 1(1), 1-6. https://doi.org/10.1186/2191-1991-1-11

Maharani, A., \& Tampubolon, G. (2015). Has decentralisation affected child immunisation status in Indonesia? Global Health Action, 8(1). https://doi.org/10.3402/gha.v7.24913

McNeil, D. A., Mueller, M., MacDonald, S., McDonald, S., Saini, V., Kellner, J. D., \& Tough, S. (2019). Maternal perceptions of childhood vaccination: Explanations of reasons for and against vaccination. BMC Public Health, 19(1), 1-12. https://doi.org/10.1186/s12889-018-6338-0

Mitchell, A. D., Bossert, T. J., Yip, W., \& Mollahaliloglu, S. (2008). Health worker densities and immunization coverage in Turkey: A panel data analysis. Human Resources for Health, 6, 1-16. https://doi.org/10.1186/1478-4491-6-29

Nazri, C., Yamazaki, C., Kameo, S., Herawati, D. M. D., Sekarwana, N., Raksanagara, A., \& Koyama, H. (2016). Factors influencing mother's participation in Posyandu for improving nutritional status of children under-five in Aceh Utara district, Aceh province, Indonesia. BMC Public Health, 16(1), 1-9. https://doi.org/10.1186/s12889. 016-2732-7

Paramita, S. A., Yamazaki, C., Setiawati, E. P., \& Koyama, H. (2018). Distribution trends of Indonesia's health care resources in the decentralization era. The International Journal of Health Planning and Management, 33(2), e586-e596. https://doi.org/10.1002/hpm.2506 
Setiyowati, W., \& Nurhaeni, N. (2019). Does Complete Basic Immunization Correlate with Pneumonia Incidents in Children under Five Years in Depok, Indonesia? Comprehensive Child and Adolescent Nursing, 42(sup1), 291-299. https://doi.org/10.1080/24694193.2019.1594462

Trentini, F., Poletti, P., Melegaro, A., \& Merler, S. (2019). The introduction of "No jab, No school" policy and the refinement of measles immunisation strategies in high-income countries. BMC Medicine, 17(1), 1-8. https://doi.org/10.1186/s12916-019-1318-5

van Doorslaer, E., Koolman, X., Jones, A. M., Hirano, D., Campbell, J. Y. J., Wang, S. I., Yaung, C. L., Weinstein, J. N., Geller, A., Negussie, Y., Baciu, A., Shavers, V. L., Shavers, B. S., Tafuri, S., Gallone, M. S., Cappelli, M. G., Martinelli, D., Prato, R., Germinario, C., ... Tampubolon, G. (2018). Factors affecting acceptance of immunization among children in rural Bangladesh. Social Science and Medicine, 4(1), 1. https://doi.org/10.1186/s13561-016-0137-z 